\title{
Mutations in the 23S rRNA Gene of Helicobacter pylori Associated with Clarithromycin Resistance
}

\begin{abstract}
Among 12 clarithromycin-resistant Helicobacter pylori strains isolated in Guri, Korea, 8 showed an adenine to guanine mutation at position 2143 (formerly A2144G or E. coli 2059) in the 23S rRNA gene by the PCR-restriction fragment length polymorphism (RFLP) method. The remaining 4 strains, digested by neither Bsal nor Bbsl, showed a thymine to cytosine mutation at position 2182 (T2182C) by direct sequencing of the PCR products. The T2182C mutants showed a tendency of higher levels of minimum inhibitory concentration to clarithromycin than the A2143G mutants. In conclusion, either the A2143G or the T2182C mutation was present in $100 \%$ of clarithromycin-resistant $H$. pylori isolates examined. The PCRRFLP technique with restriction enzymes $B b s l$ and $B$ sal was a rapid and relatively simple method to detect the clarithromycin resistance. But undigested isolates were quite frequent among our isolates (33.3\%), the PCR-RFLP method with restriction enzymes Bbsl and Bsal should not be used alone, and development of other rapid detection method for clarithromycin resistance is mandatory.
\end{abstract}

Key Words : Helicobacter pylori; Clarithromycin; Resistance; $23 S$ rRNA Gene; Mutation

\section{Kyung Suk Kim, Jung Oak Kang*, Chang Soo Eun ${ }^{\dagger}$, Dong Soo Han', Tae Yeal Choi}

Department of Clinical Pathology, Major Woman's Hospital; Department of Clinical Pathology* and Internal Medicine ${ }^{\dagger}$, College of Medicine, Hanyang University, Seoul, Korea

Received : 1 April 2002

Accepted : 7 June 2002

\section{Address for correspondence}

Jung Oak Kang, M.D.

Department of Clinical Pathology, Hanyang

University Guri Hospital, 249-1 Kyomundong, Guri 471-701, Korea

Tel : +82.31-560-2572, Fax : +82.31-560-2585

E-mail : jokang@hanyang.ac.kr

*This work was supported by a grant from Hanyang University, Korea, made in the program year of 2001.

\section{INTRODUCTION}

The prevalence rate of antimicrobial resistance to Helicobacter pylori varies with geographical regions, but almost all $H$. pylori strains are susceptible to amoxicillin, while 1 to $13 \%$ of strains are resistant to clarithromycin and 20 to $70 \%$ of strains are resistant to metronidazole (1-3). In Korea, the prevalence rate of metronidazole resistance approaches $50 \%$, but the clarithromycin resistance rate was reported to be below $5 \%$, however, has begun to increase recently $(4,5)$. Therefore the most widely used primary regimen for $H$. pylori eradication in Korea is the triple therapy with clarithromycin, amoxicillin, and a proton-pump inhibitor.

The impact of antimicrobial resistance on the eradication of $H$. pylori has been reviewed by several investigators (6-8). The cure rate with metronidazole-based combination regimens in patients with metronidazole-resistant strains was decreased by 20 to $50 \%$, compared to patients harboring metronidazole-susceptible strains $(6,7)$. In case of clarithromycin resistance, the efficacy of clarithromycin-based triple therapy was also decreased by more than $50 \%$ (8). Therefore, in Korea or elsewhere, the clarithromycin resistance is a prime concern for clinicians who treat the ulcer patients infected with $H$. pylori. Clinical microbiology laboratory of Hanyang University Guri Hospital routinely performs the antimicrobial susceptibility testing of $H$. pylori for clarithromycin since
1996 by the modified broth microdilution method (4). As culture and susceptibility testing of $H$. pylori are time- and labor-demanding procedure, we have tried to develop rapid detection methods for clarithromycin resistance by molecular methods.

Versalovic et al. showed that point mutations in two positions (A to $\mathrm{G}$ at 2142, 2143) in $23 \mathrm{~S}$ rRNA domain $\mathrm{V}$ were associated with macrolide resistance (9). With appropriate restriction enzymes (BbsI and BsaI) and the PCR-restriction fragment length polymorphism (RFLP) technique, Occhialini et al. developed a relatively simple method detecting these mutations (10). The aim of this study was to detect the point mutations in the peptidyltransferase region of $23 \mathrm{~S}$ rRNA and to evaluate the molecular method for the detection of clarithromycin-resistant $H$. pylori isolates from Guri, Korea.

\section{MATERIALS AND METHODS}

\section{Isolation and identification}

H. pylori were isolated from gastric biopsy specimens from patients diagnosed as peptic ulcer or gastric carcinoma from 1996 through 2001 in Hanyang University Guri Hospital. Culture was performed on brain heart infusion (BHI) agar containing $5 \%$ sheep blood and the inoculated plates were 
incubated at $37^{\circ} \mathrm{C}$ for 3 to 6 days under microaerobic conditions generated by Campy-Pak Plus (BBL Microbiology System, Cockeysville, Md., U.S.A.). Identification was based on the Gram stain morphology and the presence of oxidase, catalase, and urease activities.

\section{Antimicrobial susceptibility testing}

Minimum inhibitory concentrations (MICs) were determined by the modified broth microdilution method as described by Kim et al. (4). Isolates were subcultured for $72 \mathrm{hr}$ and saline suspensions of No. $2 \mathrm{McF}$ arland standard were prepared. Serial dilutions of clarithromycin at concentrations ranging from 0.125 to $64 \mu \mathrm{g} / \mathrm{mL}$ were prepared in distilled water. A suspension of each isolate was inoculated into the clarithromycin-containing 96-well microplate. Plates were incubated at $37^{\circ} \mathrm{C}$ for 3 days under microaerobic condition, and the MIC was recorded as the lowest concentration of the antibiotic inhibiting the visible growth of $H$. pylori. Resistance was defined as the clarithromycin MIC being $\geq 1 \mu \mathrm{g} / \mathrm{mL}$ (11).

\section{Detection of mutations}

Genomic DNA was extracted from lysed $H$. pylori with InstaGene ${ }^{\mathrm{TM}}$ Matrix (Bio-Rad Lab. Hercules, CA). Two pairs of PCR primers were used to amplify two fragments of the peptidyltransferase region of the $23 \mathrm{~S}$ rRNA. The sequences of the primers were based on the published sequence of the 23S rDNA gene of $H$. pylori (GenBank accession number U27270). Primers K1 (5'- CCA CAG CGA TGT GGT CTC AG-3' corresponding to position 2191 to 2210) and K2 (5'CTC CAT AAG AGC CAA AGC CC-3' complementary to position 2596 to 2615) were used to amplify fragment A of 425 bp. Primers K3 (5'- GCA CAA GCC AGC CTG ACT G-3' corresponding to position 2786 to 2804) and K4 (5'AGC AGT TAT CAC ATC CGT G -3' complementary to position 3181 to 3199 ) were chosen to amplify fragment B of $414 \mathrm{bp}(10)$.

PCR amplification of DNA was performed in a final volume of $50 \mu \mathrm{L}$ containing $1 \mu \mathrm{g}$ of $H$. pylori genomic DNA, 75 $\mathrm{mM}$ Tris- $\mathrm{HCl}(\mathrm{pH} 8.8), 20 \mathrm{mM}\left(\mathrm{NH}_{4}\right)_{2} \mathrm{SO}_{4}, 0.01 \%$ Tween $20,1.5 \mathrm{mM} \mathrm{MgCl}_{2}, 0.2 \mathrm{mM}$ concentration of deoxynucleoside triphosphate mixture, $1 \mu \mathrm{M}$ concentration of primers and $2 \mathrm{U}$ of Taq DNA polymerase. The cycling program was 1 cycle at $95^{\circ} \mathrm{C}$ for $5 \mathrm{~min} ; 35$ cycles of $95^{\circ} \mathrm{C}$ for $30 \mathrm{sec}, 54$ ${ }^{\circ} \mathrm{C}$ for $30 \mathrm{sec}, 72^{\circ} \mathrm{C}$ for $30 \mathrm{sec}$; and a final elongation step at $72^{\circ} \mathrm{C}$ for $10 \mathrm{~min}$.

The amplified products (fragment A amplicon) were digested with BbsI and BsaI (New England Biolabs, Inc., Beverly, Mass., U.S.A.) as described by Occhialini et al. (1997), which allow discrimination between the wild type, the A2142G mutant (BbsI restriction site), and the A2143G mutant (BsaI restriction site). Ten microliters of the amplicon A (425 bp) was incubated for $24 \mathrm{hr}$ at $56^{\circ} \mathrm{C}$ for $\mathrm{BsaI}$ and at $37^{\circ} \mathrm{C}$ for $B b s I$ in order to detect the restriction site occurring when the mutation was A to $G$ at 2143 (formerly 2144) or at 2142 (formerly 2143), respectively. The restriction products were analyzed by electrophoresis on $2 \%$ agarose gel.

PCR products were purified and concentrated with an agarose gel DNA extraction kit (Roche, Germany). The same primers for PCR amplification were used for sequencing. Sequencing was performed on the two strands of each amplicon with an automated DNA sequencer (the ABI PRISM $377 \mathrm{XL}$ ) and with the sequencing kit (Perkin-Elmer).

\section{RESULTS}

Among the 271 clinical isolates of $H$. pylori from 1996 through 2001, 18 isolates (6.6\%) showed clarithromycin resistance. MIC distribution of the 18 clarithromycin-resistant strains varied from $1 \mu \mathrm{g} / \mathrm{mL}$ in $16.7 \%, 2 \mu \mathrm{g} / \mathrm{mL}$ in $5.6 \%, 4$ $\mu \mathrm{g} / \mathrm{mL}$ in $11.1 \%, 8 \mu \mathrm{g} / \mathrm{mL}$ in $16.7 \%, 16 \mu \mathrm{g} / \mathrm{mL}$ in $5.6 \%$, $32 \mu \mathrm{g} / \mathrm{mL}$ in $5.6 \%$, and $\geq 64 \mu \mathrm{g} / \mathrm{mL}$ in $38.9 \%$. Among the 12 resistant isolates that were available for the PCR, BsaI restriction enzyme cut the PCR-products of 8 strains to 304 bp and 101 bp bands (Fig. 1), indicating that the 8 strains had an A to $G$ mutation at position 2143 (A2143G). Neither $B b s \mathrm{I}$ nor $B s a \mathrm{I}$ digested the PCR products of remaining the 4 strains. On sequencing the PCR products of these 4 strains, all four isolates showed a point mutation of $\mathrm{T}$ to $\mathrm{C}$ at position 2182 (T2182C). MICs of the A2143G mutant strains were relatively low from 1 to $8 \mu \mathrm{g} / \mathrm{mL}$, except two isolates (both, $\geq 64 \mu \mathrm{g} / \mathrm{mL}$ ). In contrast, MICs of the T2182C mutants were relatively high from $16 \mu \mathrm{g} / \mathrm{mL}$ to $\geq 64 \mu \mathrm{g} / \mathrm{mL}$

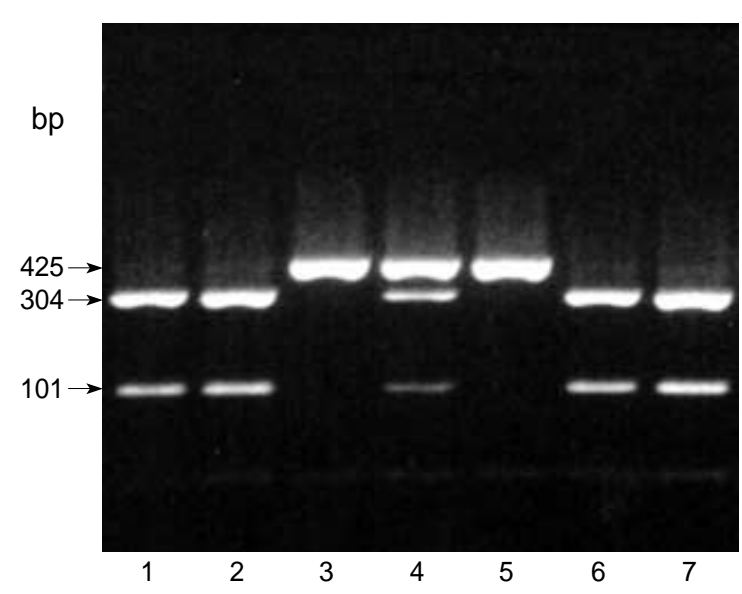

Fig. 1. Ethidium bromide-stained agarose gel displaying the restriction profiles of fragment $A(425 \mathrm{bp}$ ) treated with Bsal for clarithromycin-resistant $H$. pylori strains. Lanes $1,2,4,6$, and 7 reveal digestion into $304 \mathrm{bp}$ and $101 \mathrm{bp}$ products, which means an A to $\mathrm{G}$ mutation at position 2143. Lanes 3 and 5; not digested with either Bbsl or Bsal. Sequencing of the PCR products revealed a $\mathrm{T}$ to $\mathrm{C}$ mutation at position 2182. 
Table 1. Minimum inhibitory concentrations (MIC) and mutation profiles of the clarithromycin-resistant $H$. pylori isolates

\begin{tabular}{lrc}
\hline Isolates & Clarithromycin MIC $(\mu \mathrm{g} / \mathrm{mL})$ & Mutation site \\
\hline $97-169$ & $\geq 64$ & A2143G \\
$98-016$ & 8 & A2143G \\
$99-100$ & 2 & A2143G \\
$99-138$ & 4 & A2143G \\
$99-145$ & 8 & A2143G \\
$00-150$ & 1 & A2143G \\
$01-044$ & 8 & A2143G \\
$01-065$ & $\geq 64$ & A2143G \\
$99-084$ & $\geq 64$ & T2182C \\
$99-120$ & $\geq 64$ & T2182C \\
$00-004$ & 16 & T2182C \\
$01-045$ & $\geq 64$ & T2182C \\
$96-153$ & $\geq 64$ & Not done \\
$97-025$ & 32 & Not done \\
$99-102$ & 4 & Not done \\
$00-028$ & 1 & Not done \\
$00-028$ & 1 & Not done \\
$01-085$ & 1 & Not done \\
\hline
\end{tabular}

\section{(Table 1).}

PCR-RFLP analysis of 14 clarithromycin-susceptible (< $0.5 \mu \mathrm{g} / \mathrm{mL}$ ) strains of $H$. pylori showed neither A2142G nor A2143G mutations. The PCR products of the four isolates among the 14 undigested clarithromycin-susceptible $H$. pylori were sequenced, but disclosed no mutation sites.

\section{DISCUSSION}

The clarithromycin resistance is a prime concern for physicians who are using clarithromycin-based triple therapy as a primary regimen for ulcer patients infected with $H$. pylori. Physicians ask for an antimicrobial susceptibility testing for clarithromycin, but the culture of this fastidious bacterium takes time and effort, and moreover, antimicrobial susceptibility testing is not practically possible for most clinical microbiology laboratories due to its technical difficulty, cost, and labor. One solution to this problem is offered by the techniques based on PCR.

Resistance to macrolides is caused by a decrease in binding of macrolides to the ribosome, which is associated with Erm methylation of A2058 (Escherichia coli numbering) or mutation at A2058 of $23 \mathrm{~S}$ rRNA $(12,13)$. In 1996, Versalovic et al. first reported the association of clarithromycin resistance of $H$. pylori with a single point mutation within the domain $\mathrm{V}$ of $23 \mathrm{~S} \mathrm{r}$

RNA (9). They identified A to $G$ transition mutations at positions cognate with Escherichia coli $23 \mathrm{~S}$ rRNA positions 2058 and 2059, and later named them positions 2143 and 2144 according to the entire $H$. pylori $23 \mathrm{~S}$ rRNA sequence by GenBank no. U27270 (14). Taylor et al. determined the DNA sequences of the two copies of the $23 \mathrm{~S}$ rRNA gene from

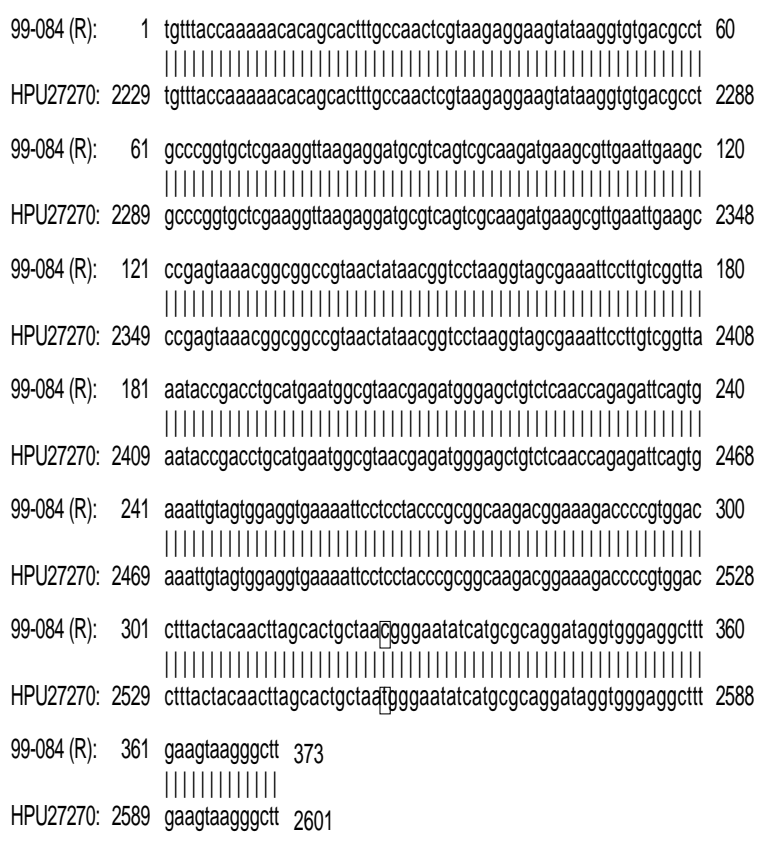

Fig. 2. Nucleotide sequence alignment of the domain $\mathrm{V}$ in $23 \mathrm{~S}$ rRNA of T2182C mutant strain. The 99-084(R) is a clarithromycinresistant $H$. pylori, of which the MIC is $\geq 64 \mu \mathrm{g} / \mathrm{mL}$. Numbering of nucleotide position followed the proposed system by Taylor et al. (position 2554-373+1= position 2182). The HPU27270 is the published sequence of the 23S rRNA gene of H. pylori (GenBank accession number U27270). The boxed letter indicates T2182C point mutation.

H. pylori UA802 and compared the sequences from clarithromycin-resistant strains. They defined the $5^{\prime}$ end of the $H$. pylori $23 \mathrm{~S}$ rRNA as position $373 \mathrm{~A}$, and therefore, they proposed that the positions associated with clarithromycin resistance within the $H$. pylori $23 \mathrm{~S}$ rRNA be defined as nucleotides 2142 and 2143 . Most investigators choose to numerate the residues 2142 and 2143 according to the definition of the structure of the $23 \mathrm{~S}$ rRNA gene in $H$. pylori published by Taylor et al. (15).

The prevalence of mutant strains among the clarithromycin-resistant $H$. pylori varies in different parts of the world. Studies from U.S.A. revealed $48 \%$ to $53 \%$ of A2142G mutation, $39 \%$ to $45 \%$ of $\mathrm{A} 2143 \mathrm{G}$ mutation, and $0 \%$ to $7 \%$ of A2142C mutation $(14,16)$. The prevalence of the A2142G mutation in Europe was reported as $23 \%$ to $33 \%$, A2143G mutation as $44 \%$ to $67 \%$, and $\mathrm{A} 2142 \mathrm{C}$ mutation as $2 \%$ to $10 \%(17,18)$. However, studies from Japan $(19,20)$ showed that more than $90 \%$ of the mutant strains had the A2143G mutation and the A2142C mutation was not detected. Although the number of the strains was small, a study from China also showed $100 \%$ of A2143G mutation in clarithromycin-resistant $H$. pylori (21).

The incidence of clarithromycin resistance in $H$. pylori isolated in Korea has been reported below 10\%, but the preva- 
lence of resistant strains is increasing due to the widespread use of macrolides as a primary regimen for $H$. pylori infections or for the treatment of respiratory tract infection in pediatric patients $(4,5)$. Therefore, characterization of the resistance mechanism in each country will facilitate the development of a rapid detection method, the choice of appropriate treatment regimens, and ultimately, the control of the infection.

In our study, all the 12 clarithromycin-resistant strains isolated at Hanyang University Guri Hospital had point mutations at the $23 \mathrm{~S}$ rRNA gene of $H$. pylori. The most prevalent mutation was A2143G (66.7\%) and the A2142G mutants were not identified. Our results are different from those of Europe or U.S.A. (14, 16-18), but similar with those of Japan and China where the major type of mutation was reported as A2143G (19-21). One study from Korea revealed that A2142G mutation was observed in $87.0 \%$, and A2143G mutation in $13.0 \%$ (22). But in the results of Song et al. (23), three of four clarithromycin-resistant isolates showed A2143G mutation and one isolate showed $\mathrm{C} 2215 \mathrm{~T}$ mutation. In $H$. pylori, seven different point mutations (A2142G or C, A2143G or C, A2115G, G2141A, and A2142T) in the 23S rRNA gene have been found to be associated with the resistance to clarithromycin (18, 24).

Most notable finding of our study is the T2182 to C mutation that has not been reported in $H$. pylori isolated in Korea. The $A$ to $G$ transition mutation is presently the most frequent substitution and has genetic stability and growth advantage compared to the wild-type strain or to strains with any of other bases at these positions $(17,25)$. Also, the A2142G gives the highest level of resistance to clarithromycin, but the A2143G mutants have lower levels of clarithromycin resistance than the A2142G mutants (14). Our results also showed that the $\mathrm{A} 2143 \mathrm{G}$ mutation was related to the low levels of clarithromycin MICs. Although the underlying mechanism for this phenomenon has not been known, the T2182C mutation seems to be associated with high levels of clarithromycin resistance in $H$. pylori isolated in Guri, Korea.

In conclusion, we found a rare mutation site (T2182C) from the clarithromycin-resistant $H$. pylori strains isolated in Guri, Korea. To prove the association of T2182C mutation with the clarithromycin resistance, further study will be needed. The A2143G mutation was quite frequently observed (8/12) and the T2182C mutation (4/12) was also observed. The A2142G mutation was not found in this study. Because the T2182C mutation was quite frequent among our isolates, the PCR-RFLP method with restriction enzymes BbsI and $B s a \mathrm{I}$ should not be used alone, and development of other rapid detection method for clarithromycin resistance is mandatory.

\section{ACKNOWLEDGMENTS}

This work was supported by a grant from Hanyang Uni- versity, Korea, made in the program year of 2001.

\section{REFERENCES}

1. Megraud F, Stuart H, Glupczynski Y. Antibiotic susceptibility and resistance. In: Mobley HLT, Mendz GL, and Hazell SL, eds. Helicobacter pylori: Physiology and genetics. Washington, DC: ASM press 2001: 511-30.

2. O'Morain C, Montague S. Challenges to therapy in the future. Helicobacter 2000; 5 (Suppl 1): S23-6.

3. Adamek RJ, Suerbaum S, Pfaffenbach B, Opferkuch W. Primary and acquired Helicobacter pylori resistance to clarithromycin, metronidazole, and amoxicillin- influence on treatment outcome. Am J Gastroenterol 1998; 93: 386-9.

4. Kim ES, Kang JO, Han D, Park PH, Park IK, Choi TY. Comparison of modified broth microdilution method, E test and disk diffusion method for antimicrobial susceptibility testing of Helicobacter pylori. Korean J Clin Pathol 1998; 14: 559-64.

5. Kim JJ, Reddy R, Lee M, Kim JG, El-Zaatari FAK, Osato MS, Graham DY, Kwon DH. Analysis of metronidazole, clarithromycin and tetracycline resistance of Helicobacter pylori isolates from Korea. $J$ Antimicrob Chemother 2001; 47: 459-61.

6. Houben MHMG, Van de Beek D, Hensen EF, De Craen AJM, Rauws EAJ, Tytgat GNJ. A systematic review of Helicobacter pylori eradication therapy-the impact of antimicrobial resistance on eradication rates. Aliment Pharmacol Ther 1999; 13: 1047-55.

7. Megraud F, Lehn N, Lind T, Bayerdorffer E, O’Morain C, Spiller R, Unge P, van Zanten SV, Wrangstadh M, Burman CF. Antimicrobial susceptibility testing of Helicobacter pylori in a large multicenter trial: the MACH 2 study. Antimicrob Agents Chemother 1999; 43 : 2747-52.

8. Dore MP, Leandro G, Realdi G, Sepulveda AR, Graham DY. Effect of pretreatment antibiotic resistance to metronidazole and clarithromycin on outcome of Helicobacter pylori therapy: a meta-analytical approach. Dig Dis Sci 2000; 45: 68-76.

9. Versalovic J, Shortridge D, Kibler K, Griffy MV, Beyer J, Flamm RK, Tanaka SK, Graham DY, Go MG. Mutations in 23S rRNA are associated with clarithromycin resistance in Helicobacter pylori. Antimicrob Agents Chemother 1996; 40: 477-80.

10. Occhialini A, Urdaci M, Doucet-Populaire F, Bebear CM, Lamouliatte $\mathrm{H}$, Megraud F. Macrolide resistance in Helicobacter pylori: rapid detection of point mutations and assays of macrolide binding to ribosomes. Antimicrob Agents Chemother 1997; 41: 2724-8.

11. NCCLS document M7-A5. Performance standards for antimicrobial susceptibility testing: 10th informational supplement (Aerobic dilution) 2000; 20: M100-S10 p39.

12. Weisblum B. Erythromycin resistance by ribosome modification. Antimicrob Agents Chemother 1995; 39: 577-85.

13. Vester B, Douthwaite S. Macrolide resistance conferred by base substitutions in 23 S rRNA. Antimicrob Agents Chemother 2001; 45: 1 12.

14. Versalovic J, Osato MS, Spakovsky K, Dore MP, Reddy R, Stone GG, Shortridge D, Flamm RK, Tanaka SK, Graham DY. Point mutation in the 23S rRNA gene of Helicobacter pylori associated with different levels of clarithromycin resistance. J Antimicrob Chemother 
1997; 40: 283-6.

15. Taylor DE, Ge Z, Purych D, Lo T, Hiratsuka K. Cloning and sequence analysis of two copies of a 23S rRNA gene from Helicobacter pylori and association of clarithromycin resistance with $23 \mathrm{~S}$ rRNA mutations. Antimicrob Agents Chemother 1997; 41: 2621-8.

16. Stone GG, Shortridge D, Versalovic J, Beyer J, Flamn RK, Graham DY, Ghoneim AT, Tanaka SK. PCR oligonucleotide ligation assay to determine the prevalence of $23 \mathrm{~S}$ rRNA gene mutations in clarithromycin-resistant Helicobacter pylori. Antimicrob Agents Chemother 1997; 41: 712-4.

17. Alarcon T, Domingo D, Prieto N, Lopez-Brea M. Clarithromycin resistance stability in Helicobacter pylori: influence of the MIC and type of mutation in the $23 S$ rRNA. J Antimicrob Chemother 2000; 46: 613-6.

18. Doorn LJ, Glupczynski Y, Kusters JG, Megraud F, Midolo P, MaggiSolca N, Queiroz DMM, Nouhan N, Stet E, Quint WGV. Accurate prediction of macrolide resistance in Helicobacter pylori by a PCR line probe assay for detection of mutations in the 23S rRNA gene: multicenter validation study. Antimicrob Agents Chemother 2001; 45: 1500-4.

19. Maeda S, Yoshida H, Matsunaga H, Ogura K, Kawamata O, Shiratori Y, Omata M. Detection of clarithromycin-resistant Helicobacter pylori strains by a preferential homoduplex formation assay. $J$ Clin Microbiol 2000; 38: 210-4.

20. Kato S, Fujimura S, Udagawa H, Shimizu T, Maisawa S, Ozawa K,
Iinuma K. Antibiotic resistance of Helicobacter pylori strains in Japanese children. J Clin Microbiol 2002; 40: 649-53.

21. Pan ZJ, Su WW, Tytgat GNJ, Dankert H, Ende A. Assessment of clarithromycin-resistant Helicobacter pylori among patients in Shanghai and Guangzhou, China, by primer-mismatch PCR. J Clin Microbiol 2002; 40: 259-61.

22. Nam SW, Roe IH, Kim SB, Lee BS, Hwang YJ, Park HJ, Kim JW, Lee JH, Shin JH, Yu KA. Detection of clarithromycin-resistant Helicobacter pylori by polymerase chain reaction. Korean J Gastroenterol 2000; 36: 450-6.

23. Song HJ, Chung IS, Kim SW, Lee GM, Kim BW, Lee DS, Yang YS, Han SW, Park DH, Lee JH. Antimicrobial resistance rates in Helicobacter pylori and detection of $23 S$ rRNA mutation associated with clarithromycin resistance. Korean J Gastroenterol 2000; 36 : 597-606.

24. Hülten K, Gibreel A, Sköld O, Engstrand L. Macrolide resistance in Helicobacter pylori: mechanism and stability in strains from clarithromycin-treated patients. Antimicrob Agents Chemother 1997; 41: 2550-3.

25. Debets-Ossenkopp YJ, Brinkman AB, Kuipers EJ, VandenbrouckeGrauls CMJE, Kusters JG. Explaining the bias in the 23 rRNA gene mutations associated with clarithromycin resistance in clinical isolates of Helicobacter pylori. Antimicrob Agents Chemother 1998; 42: 2749-51. 